\title{
Influence of Types and Doses of Fertilizer on the Physicochemical Characteristics of Water, Composition and Structure of Zooplankton Populations in Ponds
} \author{
Algrient Nana Towa ${ }^{1 *}$, Thomas Efole Ewoukem ${ }^{1}$, Serge Hubert Zebaze
Théophile Fonkou ${ }^{3}$, Victor Nguetsop ${ }^{3}$, Paul Zango ${ }^{4}$ and Tchoumboue ${ }^{1}$ \\ ${ }^{1}$ Laboratory of Ichtiology and Applied Hydrobiology, Faculty of Agronomy and Agricultural Sciences, Cameroon \\ ${ }^{2}$ Laboratory of Hydrobiology and Environment, Faculty of Sciences, Cameroon \\ ${ }^{3}$ Laboratory of Applied Botany, Faculty of Sciences, Cameroon \\ ${ }^{4}$ Institute of Fisheries and Aquatic Sciences, Cameroon
}

Togouet $^{2}$, Georges Fonkwa ${ }^{1}$,

*Corresponding author: Algrient Nana Towa, Laboratory of Ichtiology and Applied

Hydrobiology, Cameroon.

Received Date: April 17, 2019

Published Date: May 16, 2019

\begin{abstract}
In order to improve fish productivity, an essay on the evaluation of the comparative effect of chicken and pig manure on the composition and structure of zooplankton was conducted at the Application and Research farm from the University of Dschang (LN: 5운 $-5^{\circ} 36$ and LE: $10^{\circ} 06^{\prime}-9^{\circ}$ $85^{\prime}$ ). For this purpose, 15 ponds ( $5.7 \times 5.7 \times 1 \mathrm{~m}$ ), three doses of 0 (control); 800 and $1000 \mathrm{~kg} / \mathrm{ha}$ of chicken manure as well as pig dung were used. At each of the randomly selected ponds was administered one of the fertilizer doses every 7 days. Each of the doses and type of fertilizer representing a treatment was repeated three times. The physicochemical characteristics of the water and the zooplankton population were measured every 14 days. With respect to the physicochemical characteristics of water, the values of nitrites $(7.92 \pm 0.05 \mathrm{mg} / \mathrm{l})$, nitrates $(8.03 \pm 0.24 \mathrm{mg} / \mathrm{l})$, phosphates $(4.68 \pm 0,05 \mathrm{mg} / \mathrm{l})$ were significantly $(\mathrm{p}<0.05)$ higher in ponds fertilized at $1000 \mathrm{~kg} / \mathrm{ha}$ pig dung, the lowest being obtained in the control treatment. For zooplankton, the highest specific ( $64.51 \%$ of total species), generics ( $87.87 \%$ of total genera) and families ( $82.35 \%$ of total) zooplanktonic abundances were obtained in ponds fertilized at the rate of $1000 \mathrm{~kg} / \mathrm{ha}$ of chicken manure. The species of rotifers were the most diverse survived those of cladocerans whatever the type or the dose of fertilizer. The use of the $1000 \mathrm{~kg} / \mathrm{ha}$ dose of chicken droppings makes sense for a large production of zooplankton diversity.
\end{abstract}

Keywords: Pond; Fertilization; Chicken manure; Pig dung; Zooplankton

\section{Introduction}

In Africa and more specifically in Cameroon, the role of aquaculture in the economy remains marginal. In fact, aquaculture accounts for less than $0.1 \%$ of total fish inputs, despite the water surface area covering nearly 3.5 million hectares, spread over 4 major river basins MINEPIA [1]. It should be noted that commercial fish farming is $90 \%$ from fertilized ponds. However, one of the constraints of development of pond production is attributable to the fertilization technique associated with the mastery of the operation of the interspecific, intraspecific biodiversity of the living prey of the pond ecosystem.

Fertilization is an activity that makes it possible to optimize fish production by improving the physicochemical parameters of water and the densities of zooplankton organisms [2], which are the living prey for the most fishes. Zooplankton is by its specific diversity and nutritional value the best fish about the plasticity of the diet of fish species. Several studies have been carried out on the fertilization of ponds from animal waste [3-5], at different doses. But none of this work has focused on studying the diversity of zooplankton populations.

The objective of this work is to contribute to the improvement of the production of zooplankton intended for larval feeding through a better fertilization. More specifically, the aim is to evaluate the effect of pig manure doses on:

- The physicochemical characteristics of water 
- The richness and distribution of zooplankton populations

\section{Material and Methods}

\section{Area and period of the study}

The trial was conducted from May 15 to November 15, 2016 at the Dschang University Applied Research Farm (FAR) (LN: $5^{\circ} 44^{\prime}-5^{\circ}$ $36^{\prime}$ and LE: $10^{\circ} 06^{\prime}-9^{\circ} 85^{\prime}$, altitude: $1392-1396 \mathrm{~m}$ ) in the SudanoGuinean agro-ecological zone characterized by a short dry season (mid-November to mid-March) and a long rainy season (mid-March to mid-March) November). The annual rainfall varies between 1500 and $2000 \mathrm{~mm}$ and the temperatures oscillate between $14{ }^{\circ} \mathrm{C}$ (JulyAugust) and $25^{\circ} \mathrm{C}$ (February).

\section{Fertilizer}

The slurry and droppings used in hens came from a pork farm and egg layer layers fed a feed (feed). A sample of each fertilizer was taken to determine the total dry matter, nitrogen and phosphorus concentration. The average values of the characteristics of the droppings were: dry matter $(80.2 \pm 3.33 \%)$, total nitrogen $(2 \pm 0.14 \%)$ and total phosphorus $(1.5 \pm 0.06 \%)$ and those of pig slurry: dry matter $(30.5 \pm 2.21 \%)$, total nitrogen $(33 \pm 1.11 \%)$, total phosphorus $(9 \pm 2.30 \%)$.

\section{Experimental ponds}

The test was carried out in 15 identical by-pass ponds ( 5.7 x 5.7 $\mathrm{x} 1 \mathrm{~m}$ and a water exchange rate of $0.05 \mathrm{l} / \mathrm{s}$ ). The 15 ponds were fed in water from an artificial lake located $100 \mathrm{~m}$ away. A $1.5 \mathrm{~mm}$ mesh net was attached to the feed pipe of each pond to prevent intrusion of fish from the artificial lake.

\section{Conduct of the test and data collection}

At each randomly selected pond, one of the $0 \mathrm{~kg} / \mathrm{ha}$ (control), $800 ; 1000 \mathrm{~kg} / \mathrm{ha}$ for both chicken manure and pig dung (weighed with a $0.1 \mathrm{~g}$ precision electronic balance) corresponding to $\mathrm{T}_{0}, \mathrm{~F}_{800^{\prime}}$ $\mathrm{F}_{1000}, \mathrm{~L}_{800}$ and $\mathrm{L}_{1000}$, respectively. Fertilization was done every 7 days on the surface of each pond according to Lacroix (2004).

\section{Sampling}

The determination of the physicochemical characteristics of the water was carried out parallel to that of zooplankton every 14 days between 6 and 8 o'clock in the morning according to Agadjihouédé et al. [6] Dakwen et al. [7]. The sampling of zooplankton was carried out at twenty different points of the water column of each pond using a calibrated polyethylene container of 1 liter capacity, ie a total volume of 20 liters/pond filtered by means of a plankton screen of $40 \mu \mathrm{m}$ mesh. A volume of $350 \mathrm{ml}$ zooplankton concentrate was recovered, fixed by addition of $5 \%$ formalin ( $1 / 4$ volume of the concentrated sample) and stored in the plastic bottles for quantitative and qualitative analyzes.

\section{Determination of the physicochemical characteristics of water}

a. The transparency of the dry disk, temperature, $\mathrm{pH}$, dissolved oxygen and electrical conductivity were directly measured in the field with the help of a weighed dry disk and attached to a graduated rope, Thermo-Conductivity meter, Thermo $\mathrm{pH}$-meter, $\mathrm{pH}$ meter, thermo-oximeter and thermo-conductivity meter brand HANNA.

b. Total nitrite, nitrate and phosphate measurements were carried out by spectrophotometry (HACH DR/2000 spectrophotometer) using Alpha techniques Greenberg [8].

\section{Determination of zooplanktonic characteristics}

Two types of analysis were carried out namely: qualitative analysis and quantitative analysis.

\section{Qualitative analysis}

Only rigid integument species have been identified. Indeed, all the samples are fixed with formalin which by these chemical properties modifies the shape of the species with flexible integument. After homogenization, $10 \mathrm{ml}$ of the sample were taken by means of a calibrated pipette and introduced into a Petri dish $90 \mathrm{~mm}$ in diameter. Species identification was performed using a MOTIC brand binocular loupe.

Identification of rotifers: It was possible thanks to the use of the keys of determinations and works of [9-12].

Identification of cladocerans: It was based on the observation of morphological characters, such as the shape of the body, the shape of the cephalic capsule ventral or dorsal view, the shape of the rostrum and the detailed examination of appendages of the abdomen. The observation of these characters was only possible after dissection with the binocular loupe MOTIC using munities mounted on pen or mandrel. The keys to determinations and works were those of Rey \& Saint Jean [12-15].

Identification of copepods: The copepods are identified based on the body shape, the length of the antennules and antennas, the lateral ornamentations of the segments of the abdomen, the position of the ovigerous sacs, and the shape of the rostrum. The identification was made after dissections with the binocular magnifier MOTIC by means of the munities. The keys to determinations and works were those of Dumont [12,15-17].

\section{Quantitative analysis of zooplankton}

The counting of individuals was done simultaneously as identification. The count was done in duplicate Legendre and Watt, [18] under the binocular loupe brand MOTIC. Counts of at least 100 individuals per sample were conducted Frontier [19,20].

\section{Statistical analyzes}

The collected data were subjected to one-way analysis of variance (ANOVA 1). In case of significant differences between averages, the Duncan and Student tests were applied to separate them at the $5 \%$ significance level. The SPSS 20.0 software (Statistical Package for Social Sciences) was used for these analyzes. 


\section{Results}

\section{Influence of types and doses of fertilizer on the physicochemical characteristics of water}

The influence of fertilizer types and doses on the physicochemical characteristics of water is summarized in Table
1 and illustrated in Figure 1. Evolution of the physicochemical characteristics of water according to the types and doses of fertilizer. The trend, the profile, and the pace of the evolution of all the physicochemical characteristics of the water (Figure 1a-h) were generally comparable between the treatments.

Table 1: Physicochemical characteristics of water according to types and doses of fertilizer

\begin{tabular}{|c|c|c|c|c|c|c|}
\hline \multirow{3}{*}{$\begin{array}{l}\text { Physicochemical Charac- } \\
\text { teristic of water }\end{array}$} & \multicolumn{6}{|c|}{ Types and doses of fertilizer } \\
\hline & $\mathrm{T}_{0}$ & $F_{800}$ & $F_{1000}$ & $\mathbf{L}_{800}$ & $\mathrm{~L}_{1000}$ & $\mathbf{p}$ \\
\hline & $n=15$ & $\mathrm{n}=15$ & $n=15$ & $\mathrm{n}=15$ & $n=15$ & \\
\hline Transparency $(\mathrm{cm})$ & $74,16 \pm 10,10^{\mathrm{a}}$ & $43,26 \pm 10,61^{\mathrm{b}}$ & $32,29 \pm 2,50^{\mathrm{b}}$ & $48,34 \pm 19,81^{\mathrm{b}}$ & $55,25 \pm 13,16^{\mathrm{b}}$ & 0,02 \\
\hline Temperature $\left({ }^{\circ} \mathrm{C}\right)$ & $20,65 \pm 0,11^{a}$ & $20,42 \pm 0,35^{a}$ & $20,45 \pm 0,36^{\mathrm{a}}$ & $20,21 \pm 0,25^{\mathrm{a}}$ & $20,45 \pm 0,24^{\mathrm{a}}$ & 0,48 \\
\hline $\mathrm{O}_{2}(\mathrm{mg} / \mathrm{l})$ & $5,34 \pm 1,42^{\mathrm{a}}$ & $4,37 \pm 0,18^{\mathrm{ab}}$ & $3,53 \pm 0,18^{\mathrm{b}}$ & $4,33 \pm 0,20^{\mathrm{ab}}$ & $3,60 \pm 0,28^{\mathrm{b}}$ & 0,04 \\
\hline pH (UI) & $7,53 \pm 0,25^{a}$ & $7,44 \pm 0,22^{\mathrm{ab}}$ & $7,43 \pm 0,04^{\mathrm{ab}}$ & $7,17 \pm 0,11^{\mathrm{b}}$ & $7,42 \pm 0,05^{\mathrm{ab}}$ & 0,16 \\
\hline $\mathrm{NO}_{2}-(\mathrm{mg} / \mathrm{l})$ & $2,03 \pm 0,13^{\mathrm{a}}$ & $4,92 \pm 0,09^{\mathrm{b}}$ & $5,64 \pm 0,19^{b}$ & $7,04 \pm 0,03^{c}$ & $7,92 \pm 0,05^{\mathrm{d}}$ & 0,00 \\
\hline $\mathrm{NO}_{3}-(\mathrm{mg} / \mathrm{l})$ & $2,40 \pm 0,22^{\mathrm{a}}$ & $5,58 \pm 0,26^{\mathrm{b}}$ & $6,23 \pm 0,13^{b}$ & $7,56 \pm 0,17^{c}$ & $8,03 \pm 0,24^{\mathrm{d}}$ & 0,00 \\
\hline $\mathrm{PO}_{4}{ }^{3-}(\mathrm{mg} / \mathrm{l})$ & $1,28 \pm 0,05^{\mathrm{a}}$ & $3,34 \pm 0,07^{c}$ & $3,79 \pm 0,05^{b}$ & $3,88 \pm 0,05^{b}$ & $4,68 \pm 0,05^{\mathrm{d}}$ & 0,00 \\
\hline Conductivity $(\mu \mathrm{s} / \mathrm{cm})$ & $36,79 \pm 4,28^{\mathrm{a}}$ & $37,75 \pm 4,47^{\mathrm{a}}$ & $39,81 \pm 1,50^{\mathrm{a}}$ & $38,20 \pm 3,12^{\mathrm{a}}$ & $43,70 \pm 4,54^{\mathrm{a}}$ & 0,25 \\
\hline Trophic quotient & $0,00 \pm 00^{\mathrm{a}}$ & $1,00 \pm 00^{\mathrm{b}}$ & $0,50 \pm 00^{c}$ & $2,00 \pm 00^{\mathrm{d}}$ & $0,50 \pm 00^{c}$ & 0,00 \\
\hline
\end{tabular}

\section{Types and doses of fertilizer}

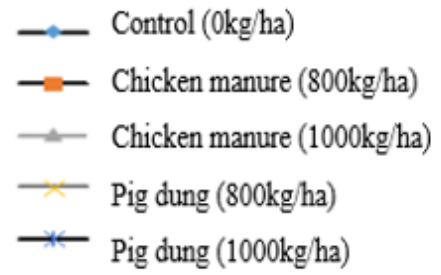

Figure 1: Evolution des caractéristiques physicochimiques de leau.

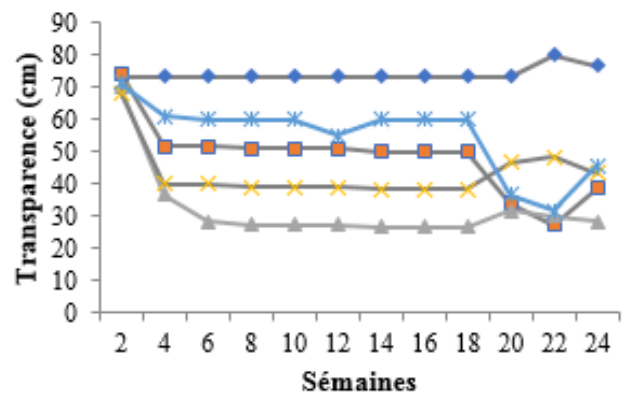

Figure 1a: Transparence.

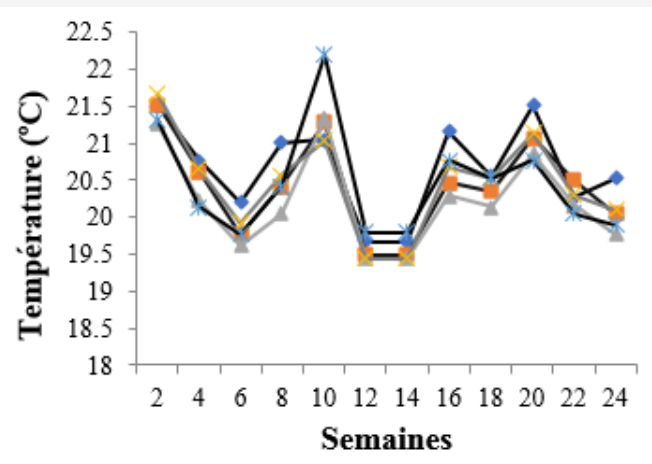

Figure 1b: Temperature.

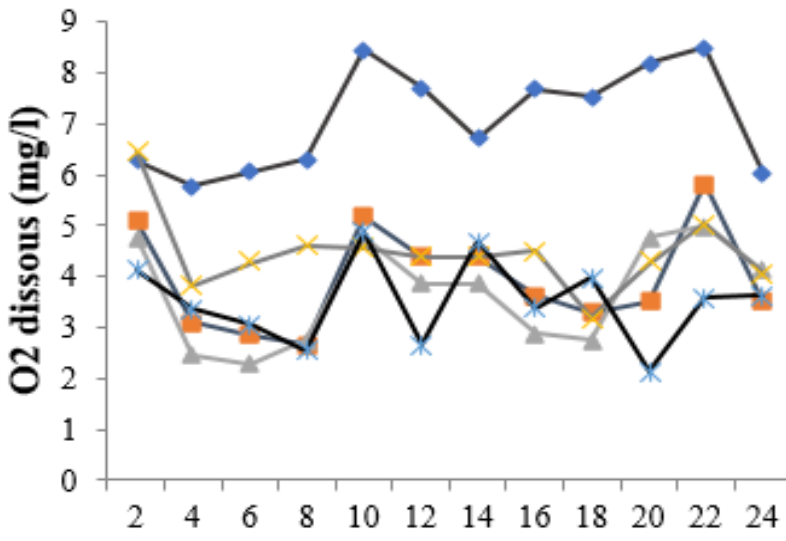

Semaines

Figure 1c: Oxygen dissous.

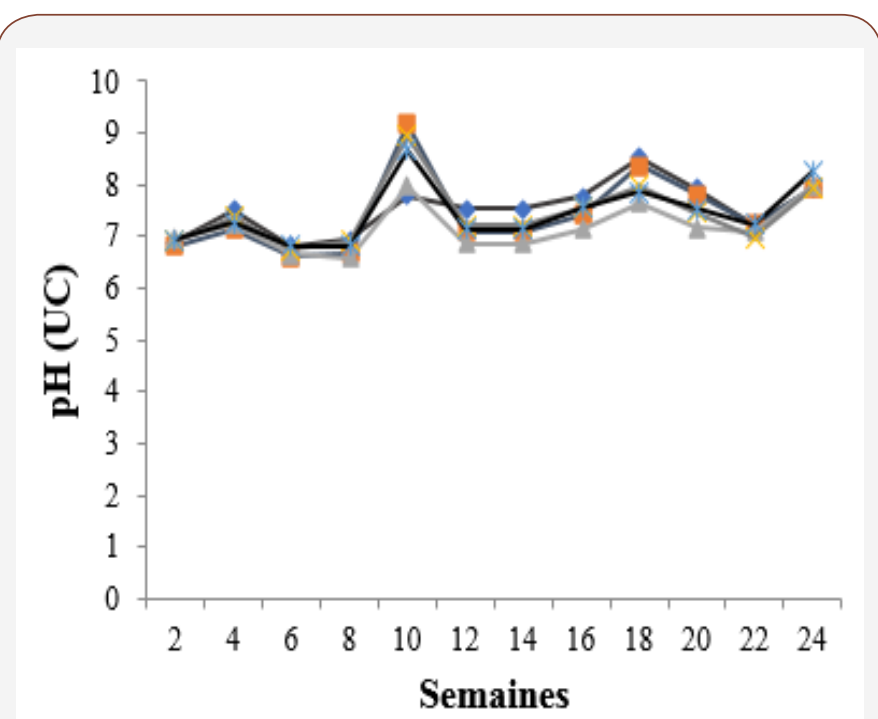

Figure 1d: $\mathrm{pH}$. 

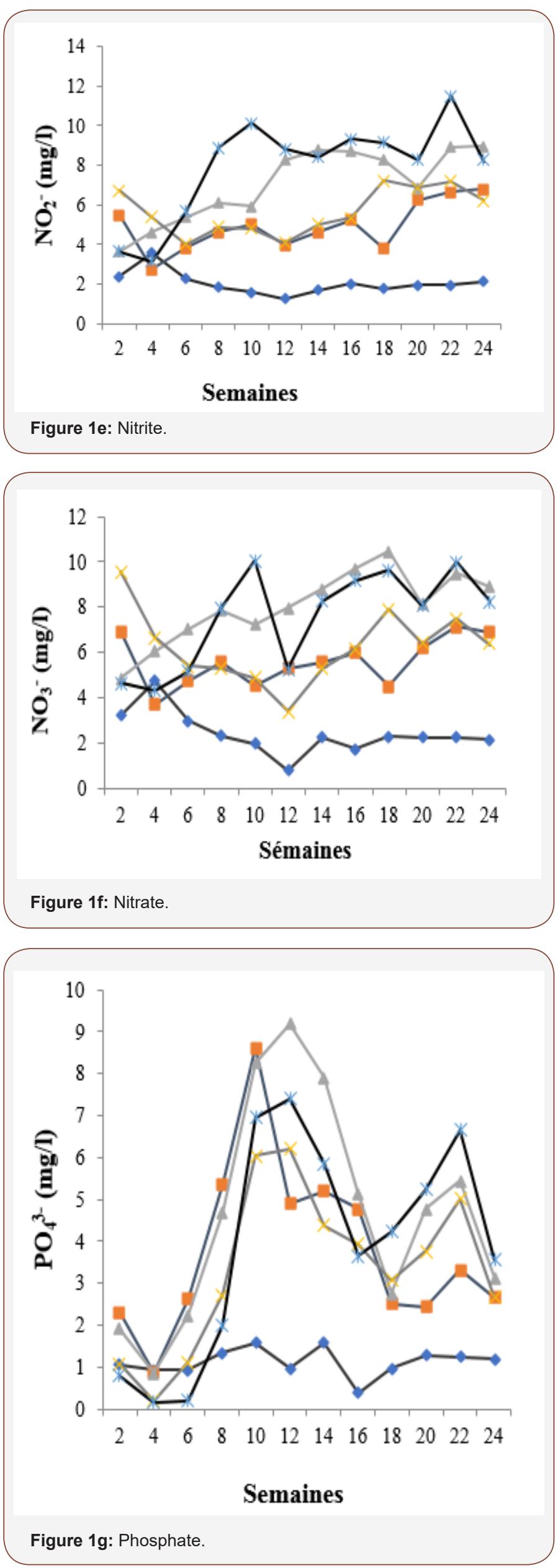

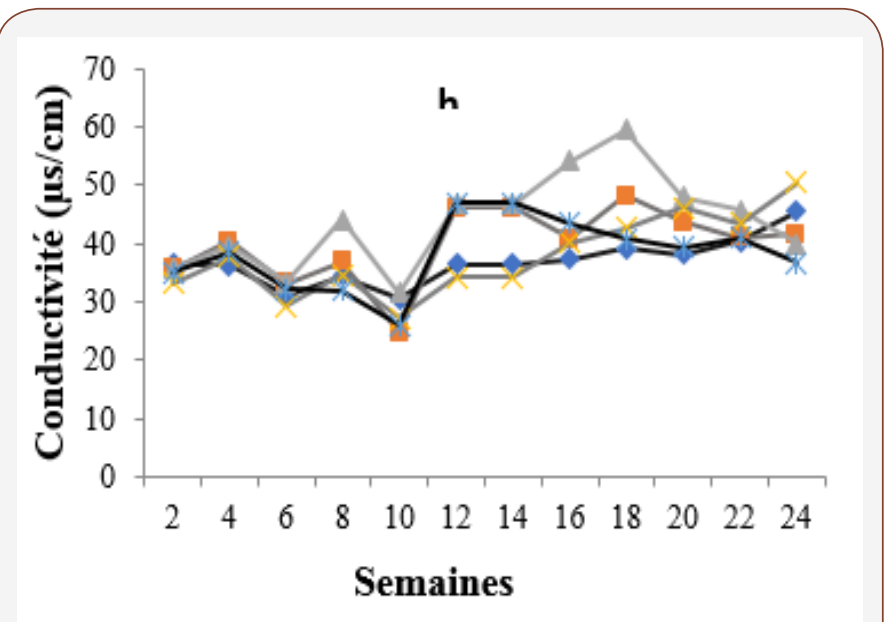

Figure 1h: Conductivity.

Transparency: The transparency as illustrated in (Figure 1a) shows that whatever the period considered the highest values significantly $(\mathrm{p}<0.05)$ are recorded in the control treatment and the lowest values in the chicken manure $(1000 \mathrm{~kg} / \mathrm{ha})$. When comparing the types of fertilizer at the same dose, the highest value of transparency is recorded in pig manure. For the same type of fertilizer, the lowest value of transparency is obtained in the largest amount of chicken droppings $(1000 \mathrm{~kg} / \mathrm{ha})$, the opposite being observed with pig manure. However, no significant differences were observed between the types and between the fertilizer doses.

Temperature and pH: The evolution of temperature (Figure $1 b)$ regardless of the period of the test was comparable between the types and doses of fertilizers. However, the highest value of the temperature at the end of the test is recorded in the control treatment (T0) and the lowest value being that fertilized at the dose of $800 \mathrm{~kg} / \mathrm{ha}$.

Whatever the period of the test, the highest $\mathrm{pH}$ values (Figure $1 d$ ) are obtained in the treatment without fertilization $\left(\mathrm{T}_{0}\right)$, followed by the dose of $800 \mathrm{~kg} / \mathrm{ha}$ of chicken manure, the lowest being with the smallest amount of pork slurry $(800 \mathrm{~kg} / \mathrm{ha})$. At the end of the test, the $\mathrm{pH}$ values were comparable between the control treatment and the two doses of chicken manure on the one hand and between the highest dose of pig manure $(1000 \mathrm{~kg} / \mathrm{ha})$ on the other hand.

Electrical conductivity: The evolution of the conductivity as illustrated in (Figure 1h) was comparable between the types and doses of fertilizer regardless of the period of the test. However, the highest value of the conductivity at the end of the test is obtained in the treatment at the rate of $1000 \mathrm{~kg} /$ ha of chicken droppings and the lowest being in the unfertilized ponds $\left(\mathrm{T}_{0}\right)$.

Dissolved oxygen trophy quotient: The evolution of dissolved oxygen (Figure 1c) shows that the highest values are recorded in the unfertilized ponds (control) and the lowest in pig manure. When comparing the same-dose fertilizer types, the dissolved oxygen values are lower in the chicken droppings at $1000 \mathrm{~kg} / \mathrm{ha}$, the reverse being with the smaller dose $(800 \mathrm{~kg} / \mathrm{ha})$. Nevertheless, no significant difference is observed between the types of fertilizers. 
Nitrites, nitrates, phosphates and trophic state: Whatever the period of the test, the lowest values for nitrites, nitrates and phosphates (Figure 1e-1g) are obtained in the control treatment without fertilization $\left(\mathrm{T}_{0}\right.$ ) (Table 1). Regardless of the period, the highest values for nitrite, nitrate and phosphates $(\mathrm{p}<0.05)$ were observed in the $1000 \mathrm{~kg} / \mathrm{ha}$ pig dung, the lowest values being obtained with the $800 \mathrm{~kg} / \mathrm{ha}$ dose of chicken manure. When comparing the types of fertilizer at equal doses, the highest values are significantly obtained in pig manure. As for the trophic quotient, the values have inversely increased with the same type and doses of fertilizer. The significantly lower value is obtained in the control treatment, the highest being recorded in the pond fertilized at the rate of $800 \mathrm{~kg} /$ ha of pig manure (Figure 1).

\section{Effects of fertilizer types and doses on species richness and distribution, zooplankton genera and families}

The influence of fertilizer types and doses on the species, genus, and family richness of zooplankton is summarized in Tables $2 \& 3$. Regardless of treatments, a total of 93 species grouped into 33 genera and 17 families were identified.

Zooplankton species: The effect of fertilizer types and doses on species richness (Table 2) shows that the highest value is obtained in ponds fertilized with the $1000 \mathrm{~kg} / \mathrm{ha}$ dose of chicken manure. The lowest value is recorded in the control treatment $\left(\mathrm{T}_{0}\right)$. When comparing the same-dose fertilizer types, the number of species recorded in the treatment with hen's droppings is higher compared to that obtained in ponds fertilized with pig manure regardless of the dose. With the same type of fertilizer, it appears that the species richness has increased with the dose both in ponds fertilized with pig manure and with chicken manure.

The distribution of zooplankton species according to fertilizer types and doses (Table 3) shows that of the 93 identified species 3, ie $3.22 \%$ (Euclanis triquetra, Lecane bulla, Polythra vulgaris), are represented in all treatments. Only one of the 93 species recorded (Lecane lunaris) is represented only in the control treatment. The numbers of species represented specifically in the treatment with pig slurry (6 species, Keratella mixta, Filinia mator, Trichocerca insulana, etc.) are the lowest compared to those obtained in ponds fertilized with chicken manure (35 species Cephalodella physalis, Resticula melandocus, Lecane aguessi, etc.).

When comparing the same fertilizer type doses, the species identified specifically in the $800 \mathrm{~kg} / \mathrm{ha}$ treatment are the lowest (1 species Lecane hamata) compared to the $1000 \mathrm{~kg} /$ ha treatment of pig dung (4 species, Keratella mixta, Filinia mator, Trichocerca insulana, etc.). The same trend is observed in lots fertilized with chicken droppings where 12 species (Cephalodella physalis, Lecane aguessi, $L$ obtusa, etc.) are specifically identified in the treatment with the smallest dose $(800 \mathrm{~kg} / \mathrm{ha}$ ) and 19 (Resticula melandocus, Lecane blachei, L doryssa, etc.) in the largest dose (1000kg/ha) (Table 2).

Table 2: Effects of fertilizer types and doses on zooplankton class richness.

\begin{tabular}{|c|c|c|c|c|c|c|}
\hline \multirow{2}{*}{ Zooplanctonic Taxonomy } & \multicolumn{7}{|c|}{ Types and doses of fertilizer (kg/ha) } \\
\cline { 2 - 7 } & Total & $\mathbf{T}_{\mathbf{0}}$ & $\mathbf{L}_{\mathbf{8 0 0}}$ & $\mathbf{L}_{1000}$ & $\mathbf{L}_{\mathbf{8 0 0}}$ & $\mathbf{L}_{\mathbf{1 0 0 0}}$ \\
\hline Species & $93(100)$ & $21(22,58)$ & $25(26,88)$ & $30(32,25)$ & $51(54,83$ & $60(64,51)$ \\
\hline Genus & $33(100)$ & $14(41,17)$ & $17(50,00)$ & $19(55,88)$ & $24(72,72)$ & $29(87,87)$ \\
\hline Families & $17(100)$ & $9(52,94)$ & $11(64,70)$ & $12(70,58)$ & $15(88,23)$ & $14(82,35)$ \\
\hline
\end{tabular}

Zooplanktonic genera: The generic richness of zooplankton (Table 3) shows that the highest value is obtained in ponds fertilized with the largest amount of chicken manure $(1000 \mathrm{~kg} / \mathrm{ha})$. The lowest value is recorded in the treatment without fertilization (control). At equal doses, the genera recorded in the treatment with chicken manure are the most numerous compared to those ponds fertilized with pig dung irrespective of the dose. When comparing the doses to the same fertilizer type, it appears that the richness of the genera enumerated increases with the dose both in ponds fertilized with pig dung and with chicken manure.

Table 3: Effects of fertilizer types and doses on the distribution of zooplankton species.

\begin{tabular}{|c|c|c|c|c|c|c|}
\hline Groups & \multicolumn{5}{|c|}{ Types and doses of fertilzer (kg/ha) } \\
\hline Families & & & & & \\
\hline Genus & & & & & \\
\hline Species & $\mathrm{T}_{0}$ & & $\mathrm{~L}_{800}$ & $\mathrm{~L}_{1000}$ & $\mathrm{~F}_{z}$ & $\mathrm{~F}_{1000}$ \\
\hline Rotifères & & & & & & \\
\hline Brachionidae & & & & & & \\
\hline Brachionus & & & & & & \\
\hline Brachionus bidentata & - & & $\mathrm{X}$ & $\mathrm{X}$ & $\mathrm{X}$ & $\mathrm{X}$ \\
\hline Brachionus quadridentatus & - & & - & $\mathrm{X}$ & $\mathrm{X}$ & $\mathrm{X}$ \\
\hline Brachionus sp. & - & & $\mathrm{X}$ & - & $\mathrm{X}$ & - \\
\hline Keratella & & & & & & \\
\hline
\end{tabular}




\begin{tabular}{|c|c|c|c|c|c|}
\hline Keratella mixta & - & - & $\mathrm{x}$ & - & - \\
\hline Keratella tropica & $\mathrm{X}$ & $\mathrm{x}$ & $\mathrm{x}$ & - & $\mathrm{X}$ \\
\hline \multicolumn{6}{|l|}{ Plationus } \\
\hline Plationus patulus & $\mathrm{X}$ & $\mathrm{x}$ & $\mathrm{x}$ & - & $\mathrm{X}$ \\
\hline \multicolumn{6}{|l|}{ Platyias } \\
\hline Platyias leloupi & - & $\mathrm{X}$ & - & $\mathrm{X}$ & $\mathrm{X}$ \\
\hline Platyias quadricornis & - & - & - & $\mathrm{X}$ & $\mathrm{X}$ \\
\hline \multicolumn{6}{|l|}{ Notommatidae } \\
\hline \multicolumn{6}{|l|}{ Cephalodella } \\
\hline Cephalodella inquila & - & $\mathrm{x}$ & - & - & $\mathrm{X}$ \\
\hline Cephalodella physalis & - & - & - & $\mathrm{x}$ & - \\
\hline Cephalolepadella bottgeri & - & - & - & $\mathrm{x}$ & $\mathrm{X}$ \\
\hline Resticula & - & - & - & - & - \\
\hline Resticula melandocus & - & - & - & - & $\mathrm{X}$ \\
\hline \multicolumn{6}{|l|}{ Dicranophoridae } \\
\hline \multicolumn{6}{|l|}{ Dicranophorus } \\
\hline Dicranophorussp. & - & - & - & - & $\mathrm{X}$ \\
\hline Dicronophorus caudatus & - & - & $\mathrm{x}$ & $\mathrm{x}$ & - \\
\hline \multicolumn{6}{|l|}{ Encentrum } \\
\hline Encentrum putorius & - & - & - & $\mathrm{x}$ & $\mathrm{X}$ \\
\hline Encentrum sp. & - & - & - & $\mathrm{X}$ & $\mathrm{X}$ \\
\hline \multicolumn{6}{|l|}{ Euchlanis } \\
\hline Euchlanis sp. & - & $\mathrm{x}$ & - & $\mathrm{x}$ & $\mathrm{X}$ \\
\hline Euchlanis triquetra & $\mathrm{X}$ & $\mathrm{x}$ & $\mathrm{x}$ & $\mathrm{X}$ & $\mathrm{X}$ \\
\hline \multicolumn{6}{|l|}{ Trochosphaeridae } \\
\hline \multicolumn{6}{|l|}{ Filinia } \\
\hline Filinia mator & - & - & $\mathrm{x}$ & - & - \\
\hline Filinia terminalis & - & $\mathrm{x}$ & $\mathrm{x}$ & $\mathrm{x}$ & - \\
\hline \multicolumn{6}{|l|}{ Lecanidae } \\
\hline \multicolumn{6}{|l|}{ Lecane } \\
\hline Lecane aguessi & - & - & - & $\mathrm{x}$ & - \\
\hline Lecane aquila & - & - & - & $\mathrm{x}$ & $\mathrm{X}$ \\
\hline Lecane blachei & - & - & - & - & $\mathrm{x}$ \\
\hline Lecane bulla & $\mathrm{X}$ & $\mathrm{x}$ & $\mathrm{x}$ & $\mathrm{x}$ & $\mathrm{X}$ \\
\hline Lecane closterocerca & - & - & - & $\mathrm{x}$ & $\mathrm{X}$ \\
\hline Lecane curvicornis & - & - & $\mathrm{x}$ & $\mathrm{x}$ & - \\
\hline Lecane decipens & - & - & - & $\mathrm{x}$ & $\mathrm{X}$ \\
\hline Lecane doryssa & - & - & - & - & $\mathrm{X}$ \\
\hline Lecane elsa & $\mathrm{X}$ & $\mathrm{x}$ & $\mathrm{x}$ & $\mathrm{x}$ & - \\
\hline Lecane hamata & - & $\mathrm{x}$ & - & - & - \\
\hline Lecane hornemanni & - & - & - & - & $\mathrm{X}$ \\
\hline Lecane luna & $\mathrm{X}$ & - & - & - & $\mathrm{X}$ \\
\hline Lecane lunaris & $\mathrm{X}$ & $\mathrm{x}$ & - & - & $\mathrm{X}$ \\
\hline Lecane nana & $\mathrm{X}$ & - & - & - & - \\
\hline Lecane obtusa & - & - & - & $\mathrm{x}$ & - \\
\hline Lecane pyriformis & - & - & - & $\mathrm{x}$ & - \\
\hline Lecane quadridentata & - & - & - & $\mathrm{x}$ & - \\
\hline Lecane stichaea & - & - & - & $\mathrm{X}$ & $\mathrm{X}$ \\
\hline
\end{tabular}




\begin{tabular}{|c|c|c|c|c|c|}
\hline Lecane tenulseta & - & - & - & $\mathrm{X}$ & - \\
\hline Lecane tudicola & - & - & - & - & $\mathrm{X}$ \\
\hline Lecane furcata & $\mathrm{X}$ & - & - & $\mathrm{X}$ & - \\
\hline \multicolumn{6}{|l|}{ Lepadellidae } \\
\hline \multicolumn{6}{|l|}{ Lepadella } \\
\hline Lepadella patella & - & - & - & - & $\mathrm{X}$ \\
\hline Lepadella sp1 & - & - & $\mathrm{x}$ & $\mathrm{X}$ & - \\
\hline Lepadella sp2 & - & - & - & $\mathrm{X}$ & - \\
\hline \multicolumn{6}{|l|}{ Xenolepadella } \\
\hline Xenolepadella monodactyla & - & - & - & - & $\mathrm{X}$ \\
\hline Xenolepadella sp. & - & - & - & - & $\mathrm{X}$ \\
\hline \multicolumn{6}{|l|}{ Mytilinidae } \\
\hline \multicolumn{6}{|l|}{ Mytilina } \\
\hline Mytilina acantophora & - & - & - & - & $\mathrm{X}$ \\
\hline Mytilina ventralis & $\mathrm{X}$ & - & $\mathrm{x}$ & - & $\mathrm{X}$ \\
\hline \multicolumn{6}{|l|}{ Synchaetidae } \\
\hline \multicolumn{6}{|l|}{ Polyathra } \\
\hline Polyathra bicerca & $\mathrm{X}$ & $\mathrm{x}$ & $\mathrm{x}$ & - & $\mathrm{X}$ \\
\hline Polyathra vulgaris & $\mathrm{X}$ & $\mathrm{x}$ & $\mathrm{x}$ & $\mathrm{x}$ & $\mathrm{X}$ \\
\hline \multicolumn{6}{|l|}{ Philodinidae } \\
\hline \multicolumn{6}{|l|}{ Rotaria } \\
\hline Rotaria rotatoria & - & $\mathrm{x}$ & $\mathrm{x}$ & - & $\mathrm{X}$ \\
\hline \multicolumn{6}{|l|}{ Scaridiidae } \\
\hline \multicolumn{6}{|l|}{ Scaridium } \\
\hline Scaridium longicaudum & - & - & - & - & $\mathrm{X}$ \\
\hline \multicolumn{6}{|l|}{ Trichocercidae } \\
\hline \multicolumn{6}{|l|}{ Trichocerca } \\
\hline Trichocerca elongata & - & - & $\mathrm{x}$ & - & $\mathrm{X}$ \\
\hline Trichocerca insulana & - & - & $\mathrm{x}$ & - & - \\
\hline Trichocerca pletessa & - & - & $\mathrm{x}$ & $\mathrm{x}$ & - \\
\hline Trichocercapusilla & - & - & - & - & $\mathrm{X}$ \\
\hline Trichocerca rattus & - & $\mathrm{x}$ & - & - & $\mathrm{X}$ \\
\hline Trichocerca scipio & - & - & - & $\mathrm{X}$ & $\mathrm{X}$ \\
\hline Trichocerca sp. & - & - & $\mathrm{x}$ & $\mathrm{X}$ & - \\
\hline \multicolumn{6}{|l|}{ Cladocères } \\
\hline \multicolumn{6}{|l|}{ Chydoridae } \\
\hline \multicolumn{6}{|l|}{ Alona } \\
\hline Alona costata & - & - & - & - & $\mathrm{X}$ \\
\hline Alona protzi & - & - & - & - & $\mathrm{X}$ \\
\hline Alona rustica & - & - & - & $\mathrm{x}$ & - \\
\hline Alona sp. & - & - & $\mathrm{x}$ & $\mathrm{X}$ & - \\
\hline Alona verrucossa & $\mathrm{X}$ & $\mathrm{x}$ & - & $\mathrm{X}$ & - \\
\hline Chydorus & - & - & - & - & - \\
\hline Chydorus brevilabris & $\mathrm{X}$ & $\mathrm{x}$ & - & - & $\mathrm{X}$ \\
\hline \multicolumn{6}{|l|}{ Bosminidae } \\
\hline \multicolumn{6}{|l|}{ Bosmina } \\
\hline Bosmina longirostris & - & - & - & $\mathrm{X}$ & - \\
\hline Bosmina sp. & $\mathrm{X}$ & - & - & $\mathrm{X}$ & - \\
\hline
\end{tabular}




\begin{tabular}{|c|c|c|c|c|c|}
\hline Bosminopsis deitersi & & & & $\mathrm{x}$ & \\
\hline \multicolumn{6}{|l|}{ Daphnidae } \\
\hline \multicolumn{6}{|l|}{ Ceriodaphnia } \\
\hline Ceriodaphnia cornuta & $\mathrm{X}$ & - & $\mathrm{x}$ & - & $\mathrm{X}$ \\
\hline Ceriodaphnia dubla & - & $\mathrm{x}$ & - & - & - \\
\hline Ceriodaphnia pulchella & $\mathrm{X}$ & $\mathrm{x}$ & - & $\mathrm{x}$ & $\mathrm{X}$ \\
\hline Ceriodaphnia quadrangula & - & - & $\mathrm{x}$ & - & $\mathrm{X}$ \\
\hline Ceriodaphnia sp. & - & - & - & - & $\mathrm{X}$ \\
\hline Simocephalus & - & - & - & - & - \\
\hline Simocephalus serrulatus & - & $\mathrm{X}$ & $\mathrm{x}$ & - & - \\
\hline Simocephalus $s p$ & - & $\mathrm{x}$ & - & $\mathrm{x}$ & - \\
\hline \multicolumn{6}{|l|}{ Diaphanosoma } \\
\hline Diaphanosoma brachyurum & - & - & - & $\mathrm{x}$ & - \\
\hline Diaphanosoma sp. & - & - & - & - & $\mathrm{X}$ \\
\hline \multicolumn{6}{|l|}{ Macrothricidae } \\
\hline \multicolumn{6}{|l|}{ Macrothrix } \\
\hline Macrothrix hirsuticornis & - & - & - & - & - \\
\hline Macrothrix laticornis & - & - & - & $\mathrm{x}$ & $\mathrm{X}$ \\
\hline \multicolumn{6}{|l|}{ Moinidae } \\
\hline \multicolumn{6}{|l|}{ Moina } \\
\hline Moina macropa & - & - & - & $\mathrm{x}$ & - \\
\hline \multicolumn{6}{|l|}{ Copépodes } \\
\hline \multicolumn{6}{|l|}{ Cyclopidae } \\
\hline \multicolumn{6}{|l|}{ Bryocyclops } \\
\hline Bryocyclops sp. & - & - & $\mathrm{X}$ & - & - \\
\hline \multicolumn{6}{|l|}{ Cryptocyclops } \\
\hline Cryptocyclops linjanticus & - & - & - & - & $\mathrm{X}$ \\
\hline Cryptocyclops sp. & $\mathrm{X}$ & & $\mathrm{x}$ & $\mathrm{x}$ & $\mathrm{X}$ \\
\hline \multicolumn{6}{|l|}{ Eucyclops } \\
\hline Eucyclops sp. & $\mathrm{X}$ & - & - & $\mathrm{x}$ & $\mathrm{X}$ \\
\hline Eucyclops stuhlmanni & - & - & - & $\mathrm{X}$ & $\mathrm{X}$ \\
\hline \multicolumn{6}{|l|}{ Halicyclops } \\
\hline Halicyclops $s p$ & - & - & - & $\mathrm{x}$ & $\mathrm{X}$ \\
\hline \multicolumn{6}{|l|}{ Mesocyclops } \\
\hline Mesocyclops salinus & $\mathrm{X}$ & - & $\mathrm{x}$ & $\mathrm{x}$ & $\mathrm{X}$ \\
\hline Mesocyclops sp. & - & - & - & $\mathrm{x}$ & $\mathrm{X}$ \\
\hline \multicolumn{6}{|l|}{ Microcyclops } \\
\hline Microcyclops sp. & - & $\mathrm{x}$ & - & $\mathrm{x}$ & $\mathrm{X}$ \\
\hline \multicolumn{6}{|l|}{ Paracyclops } \\
\hline Paracyclops sp. & - & - & - & $\mathrm{x}$ & $\mathrm{X}$ \\
\hline \multicolumn{6}{|l|}{ Thermocyclops } \\
\hline Thermocyclops emini & - & $\mathrm{x}$ & $\mathrm{x}$ & - & $\mathrm{X}$ \\
\hline Thermocyclops inopinus & - & - & - & - & $\mathrm{X}$ \\
\hline Thermocyclops neglectus & - & - & - & - & $\mathrm{X}$ \\
\hline Thermocyclops sp. & $\mathrm{X}$ & $\mathrm{X}$ & $\mathrm{X}$ & - & $\mathrm{X}$ \\
\hline
\end{tabular}

Wealth of species by genera: The specific richness of the genera according to the types and doses of fertilizer is grouped in 4 categories namely: low specific richness $\leq 2,5 \%$; average $>2.5$ and $\leq 5 \%$; high $>5$ and $\leq 7.5 \%$ and very high $>7.5 \%$ corresponding to the number or percentage of species recorded by genus. Those criteria show that of the 33 genera identified 25 or $75.75 \%$ of the 
total genera (Keratella, Plationus, Platyias, etc.), have low specific wealth. Similarly, 4 genera or $12.12 \%$ of the 33 genera identified (Brachionus, Cephalodella, Lepadella, etc.), 3 or 9.09\% (Trichocerca, Alona, Ceridaphnia) and one genus only (Lecane) have average specific wealth respectively, high and very high.

The number of genera represented by low species richness increased with the type and dose of fertilizer. Thus, the genera with low species richness are higher in the ponds fertilized with the highest dose of chicken manure (Brachionus, Keratella, Plationus, etc.) and lower in the treatment without fertilization (Keratella, Pliationus, Euchlanis, etc).

The Lecane genus with the highest species richness is recorded only in ponds fertilized with hen droppings.

Distribution of zooplanktonic genera according to types and doses of fertilizer. The distribution of zooplanktonic genera is summarized in (Table 3). A total of 6 genera or $18.18 \%$ of the 33 identified (Brachionus, Euchlanis, Lecane, Polythra, etc.) are represented in all treatments. Only one genus is specifically identified for $1000 \mathrm{~kg}$ / ha pig dung (Bryocyclops) on the one hand and ponds fertilized on the other with the lowest dose of chicken manure (Moina). A total of 3 genera (Scaridium, Xenolepadella, Resticula) are present in ponds fertilized with the largest dose of chicken droppings $(1000 \mathrm{~kg} / \mathrm{ha})$.

Zooplanktonic families: The abundance of zooplankton families according to the types and doses of fertilizer as summarized in Table 2 is highest (15 or $88.23 \%$ of total families) in ponds fertilized with the lowest dose of chicken droppings $(800 \mathrm{~kg} / \mathrm{ha})$ and the lowest ( 9 or $52.94 \%$ of the 17 families surveyed) in the treatment without fertilization (control).

When comparing fertilizers at equal doses, the wealth of the families surveyed is higher in the treatment with hen droppings compared to ponds fertilized with pig manure regardless of the dose. The distribution of zooplankton families as summarized in Table 3 shows that a total of 6 families are counted in all treatments. The families represented specifically in ponds fertilized at 800 and $1000 \mathrm{~kg} / \mathrm{ha}$ of chicken droppings are those of Moinidae and Scarididae respectively. (Table 3)

\section{Discussion}

Results concerning the influence of fertilizer types and doses on the physicochemical characteristics of water showed that dissolved oxygen, transparency, nitrite, nitrate and phosphate were significantly affected by fertilizer doses. Thus, concentrations of nitrite ions $\left(\mathrm{NO}_{2}\right)$, nitrates $\left(\mathrm{NO}_{3}\right)$ and phosphates $\left(\mathrm{PO}_{4}{ }^{3-}\right)$ were significantly higher in fertilized ponds.

The concentrations of nitrates and phosphates were comparable to those obtained by Akodogbo et al. [21] in the production of zooplankton based on pig droppings in buckets. On the other hand, they were higher than those recorded by Kumara et al. [3] in nursery tanks fertilized with chicken droppings and cow dung. Such a difference would be due to the absence of fry in our ponds that feed on organic matter or phytoplankton in suspension, responsible for the increase of mineral elements after decomposition.

The waters of the ponds fertilized with the greatest amount of fertilizer were remarkable for their low transparency. This observation is largely due to the distribution of seston elements in the water column, including plankton swarming Njine et al. [22].

Dissolved oxygen was significantly lower with the largest amount of fertilizer. On the other hand, results obtained in tanks fertilized with cow dung and pig excrement showed that dissolved oxygen was comparable between doses Agadjihouedé et al. $[21,23,24]$. Such variation would be due to the dose and frequency of fertilization of our ponds. The low value of oxygen obtained is characteristic of eutrophic media (Moss, 1998). Deoxygenation is the consequence of the oxidation of organic matter, carried out biologically or chemically Njine et al. [22].

The temperature, conductivity and $\mathrm{pH}$ were relatively constant and comparable between fertilizer types and doses. This trend was reported by Agadjihouedé et al. [23,24] and by Akodogbo et al. [21] in fermented bins based on animal waste. Observations show that fertilization does not significantly affect temperature, conductivity and $\mathrm{pH}$ whatever the fertilizer dose. Thus, the temperature and the $\mathrm{pH}$ were in the range favorable to the development of plankton, namely respectively $20-30{ }^{\circ} \mathrm{C}$; 6.5 - 7.5; advocated by Cabrallo et al. $[25,26]$.

Results on the effect of fertilizer types and doses on zooplankton biodiversity have shown that zooplankton species, species, and species richness increased significantly with fertilizer types and doses. The richness of the species identified independently of the treatments was greater than 70 and 69 species respectively obtained by Adedeji et al. [27] Dakwen et al. [7] in fish pond, as well as 30 species identified by Elegbe et al. [28] in a traditional aquaculture system, "Whedos". The differences observed would be due either to the types and doses of fertilizers, the sampling effort (twice a month versus one), the size of the plankton net $(40 \mu \mathrm{m}$ versus $64 \mu \mathrm{m}$ ) and the predation of the fish.

The specific richness of zooplankton in fertilized ponds was significantly higher compared to that of the control ponds. This trend corroborates that reported by Adedeji et al. [27,28]. This observation confirms the hypothesis that the contribution of biogenic elements in a body of water influences its planktonic richness, especially zooplankton. Indeed, in the Lake Municipal of Yaoundé qualified hypertrophe the specific wealth (131 species and subspecies) recorded by Zébazé [12] was greater than that obtained in our pond.

The distribution of species richness of zooplankton groups showed that rotifers were more dominant, followed by cladocerans regardless of treatment. The same trend was obtained by Dakwen et al. [7] in fish pond. Our results are dissimilar to those reported by Elegbe et al. [28] who achieved the dominance of cladocerans. The dominance of rotifers was previously mentioned in eutrophic 
and mesotrophic media by Shiel $[29,30]$. In fact, the dominance of rotifers is linked to the fact that they are the organisms whose mode of reproduction is the fastest of all the metazoans Nogrady et al. [31] and therefore rapidly settle the available niches.

\section{Conclusion}

At the end of the test on the influence of hog droppings and pig slurry on the physicochemical characteristics of water and the composition and structure of zooplankton populations in ponds, the main conclusions are as follows. The physicochemical characteristics of water were significantly affected by fertilizer types and doses. The nitrite, nitrate and phosphate concentrations as well as the conductivity were significantly higher in hog manure ponds at a rate of $1000 \mathrm{~kg} / \mathrm{ha}$. The higher trophic quotient in fertilized ponds showed that fertilization improved the quality of the water from the oligotrophic state to the mesotrophic control pond in a fertilized pond.

The distribution composition of species as well as zooplankton genera and families were affected by fertilizer types and doses. Indeed, the highest zooplankton species and genera richness was recorded in the treatment at $1000 \mathrm{~kg} /$ ha of chicken droppings. The species of rotifers were the most diverse survived those of cladocerans whatever the type or the dose of fertilizer. For a better production of the zooplankton diversity, it is preferable to use the dose of $1000 \mathrm{~kg} / \mathrm{ha}$ of chicken manure.

\section{Acknowledgement}

None.

\section{Conflict of Interest}

No conflict of interest.

\section{References}

1. MINEPIA (Ministère de 1 Elevage des Pêches et des Industries Animales (2009) Plan de développement durable de l aquaculture au Cameroun. In: Ministère de 1 Elevage des Pêches et des Industries Animales, Yaoundé, Cameroun, P: 55.

2. Akodogbo HH, Agadjihouèdé H, Bonou CA, Fiogbé ED (2015) Production du zooplancton à partir des déjections animales et son importance dans la vie des larves de poisson: synthèse bibliographique. Annales des Sciences Agronomiques 19(1): 97-113.

3. Kumara A, Edirisinghe U, Dematawewa CMB (2003) Effect of Chicken Manure and Cow Dung on Water Quality, Pond Productivity, and Growthand Survival of Goldfish (Carassius auratus) Fry. Tropical Agricultural Research 15: 242-255.

4. Ponce Palafox JT, Arredondo Figueroa JL, Castillo Vargasmachuca S, Rodríguez Chávez G, Benítez Valle A, et al. (2010) The effect ofchemical and organic fertilization on phytoplankton and fish production in carp (cyprinidae) polyculture system. Rev Biocienc 1: 44-50.

5. Efole ET (2011) Optimisation biotechnique de la pisciculture en étang dans le cadre du développement durable dans l exploitation familiale agricole au Cameroun. Agrocampus Thèse de doctorat à 1 Université de Dschang, pp: 176.

6. Agadjihouédé $\mathrm{H}$, Bonou CA, Lalèyè PH (2010) Effet de la fertilisation a base des fientes de volaille sur la production du zooplancton en aquarium. Annales des Sciences Agronomiques 14(1): 63-75.

7. Dakwen JP, Zébazé Togouet SH, Tuekam KRP, Djeuffa Heuchim C, Nziéleu Tchapgnouo JG, et al. (2015) Physicochemistry characterization and Zooplankton specific diversity of two fish ponds in Yaoundé (Cameroon,
Central Africa). Journal of Biodiversity and Environmental Sciences 6(2): 16-30

8. Greenberg A (1985) Standard methods for the examination of water and waste water. In: Greenberg A (Edt.), American Public Health Association, Washington, USA, pp: 1268.

9. Koste W (1978) Rotaria. Die rädertiere mitteleuropus, Born traegered (2): 1- 673.

10. Durand JR, Levêque C (1980) Flore et faune aquatiques de l Afrique Sahelo-Soudanienne. T1 ORSTOM IDT Paris, pp: 389.

11. Pourriot R, Francez AJ (1986) Rotifères. Introduction pratique à la systématique des organismes des eaux continentales françaises. Bull, Mens Soc Lin Lyon 8: 1-37.

12. Zébazé Togouet SH (2000) Biodiversité et dynamique des populations du zooplancton (Ciliés, Rotifères, Cladocères et Copépodes) au lac municipal de Yaoundé (Cameroun). Thèse de 3ème cycle, Université de Yaoundé I (Cameroun) pp: 175.

13. Rey J, Saint Jean L (1980) Branchiopodes Cladocères. In: IDT ORSTOM, Flore et faune aquatique de l Afrique sahélo-soudanienne I Paris, pp: 307-332.

14. Amoros C, Crustacés cladocères (1984) Introduction pratique à la systématique des organismes des eaux continentales françaises. Bull Mens Soc Lin Lyon 3: 53-63.

15. Fernando $\mathrm{CH}$ (2002) Introduction in a guide to tropical fresh water zooplankton. In: CH Fernando (Edt.), Identification ecology and impact on fisheries, Leiden (Netherlands), pp: 291.

16. Dumont HJ (1980) Workshop on taxonomy and biogeography. Hydrobiologia 1: 205-206.

17. Dussart H, Defaye D (1995) Copepoda. Introduction to the Copepoda. vol. 7. Guides to the Identification of the Microinvertebrates of the Continental Waters of the World. SPB Academic Publishing, Amsterdam, Netherlands, pp: 277

18. Legendre L, Watt WD (1972) On a rapid technic for plankton enumeration, Annls Int Ocean gr 60(8): 173-177.

19. Frontier S (1972) Calcul de lerreur sur un comptage de zooplancton. J exp Mar Biol Ecol 8(2): 121-132.

20. Frontier S (1973) Etude statistique de la dispersion du zooplankton. J Exp Mar Biol Ecol 12(3): 229-262.

21. Akodogbo HH, Bonou CA, Fiogbè ED (2014) Effect of pig dung fertilizer on zooplankton production. Journal of Applied Biosciences 84: 76657673.

22. Njine T, Kemka N, Zebaze Togouet SH, Nola M, Niyitegeka D, et al. (2007) Peuplement phytoplanctonique et qualité des eaux en milieu lacustre anthropisé: cas du lac municipal de Yaoundé (Cameroun). African Journal of Science and Technology (AJST), Science and Engineering Series 8(1): 39-51.

23. Agadjihouèdé H, Bonou CA, Chikou A, Lalèyè PH (2010) Production comparée de zooplancton en bassins fertilisés avec la fiente de volaille et la bouse de vache. International Journal of Biological and Chemical Sciences 4(2): 432-442.

24. Agadjihouédé H, Bonou CA, Montchowui E, Lalèyè PH (2011) Recherche de la dose optimale de fiente de volaille pour la production spécifique de zooplancton à des fins piscicoles. Cahiers Agricultures 20(4): 247-260.

25. Carballo E, Eer A, Schie T, Hilbrands A (2008) Small-scale Freshwater Fish Farming, Agrodok 15. Agromisa Foundation and CTA, Wageningen, p: 84.

26. FAO (2016) La situation mondiale des pêches et de l aquaculture. In: FAO (Edt.), Département de Pêches et Aquaculture, Rome (Italie), pp: 227.

27. Adedeji AA, Adeniyi IF, Masundire H (2013) Zooplankton abundance and diversity of fishponds exposed to different management practices. International Journal of Biological and Chemical Sciences 7(2): 631-640.

28. Elegbe AH, Blé CM, Etilé N’ doua, Chikou A, Toko I (2016) Diversity and structure of zooplankton in a tropical traditional aquaculture system 
"Whedos" in Ouémé river high delta (Benin, West Africa). Journal of Entomology and Zoology Studies 4(6): 772-779.

29. Shiel RJ (1995) A guide to identification of Rotifers, Cladocerans and Copepods from Australian inland water. CRCFE-MDBC, Albury Australie, pp: 144.
30. Shiel RJ, Green J, Nielsen DL (1998) Floodplain biodiversity: why are there so many species? Hydrobiologia 387(0): 39-46.

31. Nogrady T, Wallace RL, Snell TW (1993) Rotifera. Biology, Ecology and Systematics. The Hague: SPB Academic Publishing 1: 299. 